\title{
Impact of Liquidity on Profitability of Bank: A Case of Commercial Bank of Ethiopia
}

\author{
Tegbaru Awulo ${ }^{1} \quad$ Asnakech Alemu ${ }^{2} \quad$ Badassa Wolteji Chala ${ }^{3 *}$ \\ 1.Branch Manager, Commercial Bank of Ethiopian \\ 2. Lecture, Department of Economics, Wolkite University \\ 3. Assistant Professor, Department of Economics, Ambo University, Ethiopia
}

\begin{abstract}
The major aim of this study was to empirical investigate as how liquidity management affects profitability in commercial banks and how commercial banks can enhance their liquidity and profitability positions. The study used yearly time series data on current ratio, loan to deposit ratio and operating efficiency over the period 19862017. Autoregressive disturbed lag model (ARDL) is used to investigate the short-run and long-run effect of liquidity on profitability. Current ratio and loan to deposit ratio of the bank were used to measure liquidity while return on assets (ROA) which is dependent variable is used to measure profitability. The estimated result shows that the immediate impact of changes in the dummy variable of structural break negatively affect return on asset in the short-run. In addition, loan to deposit ratio negatively affects return on asset in the long-run. While current ratio significantly and positively affects return on asset in the long-run, it does not have an impact on return on asset or profitability (ROA) in the long-run. The study suggests that Commercial Bank of Ethiopia should evaluate and redesign its liquidity management strategy and it should be also proactive than reactive so that it will enhance its profitability overtime.
\end{abstract}

Keywords: Liquidity, Profitability, Commercial Bank of Ethiopia, autoregressive disturbed large model DOI: $10.7176 /$ RJFA/10-1-04

\subsection{Introduction}

Banks are financial institutions that play intermediary role in an economy through channeling financial resources from surplus economic units to deficit ones. In turn, banks facilitate the saving and capital formation in an economy. Financial inter-mediation role of the commercial banks hence becomes basis of the two major functions of commercial banks, namely, deposit mobilization and credit extension. The banking institution had contributed significantly to the effectiveness of the entire financial system as they offer an efficient institutional mechanism through which resources can be mobilized and directed from less essential uses to more productive investments (Wilner, 2000).

An adequate financial intermediation requires purposeful attention of bank management to profitability and liquidity, which are two conflicting goals of the commercial banks. These goals are parallel in the sense that an attempt to achieve higher profitability will certainly erode its liquidity and solvency positions and vice versa. Practically, profitability and liquidity are effective indicators of the corporate health and performance of commercial banks (Eljelly, 2004). These performance indicators are very important to the shareholders and depositors. As the shareholders are interested in the profitability level, the depositors are concerned with liquidity position which determines the bank's ability to respond to withdrawal demands. To maintain relative macro-economic stability, reliance is placed on liquidity management to even out the swings in liquidity growth in the banking system.

Profit is a necessity and a goal for commercial banks. Finance managers mostly direct their efforts to this goal to enhance shareholders' worth. To do this, banks need to remain profitable (Ignore and Kusa, 2013). Therefore, profits are not only a result, but also a necessity for successful banking in a period of growing competition in financial markets. Profit is also an essential prerequisite of a competitive banking institution and the cheapest source of funds. Bank profits provide an important source of equity especially if re-invested into the business. This should lead to safe banks, and as such high profits could promote financial stability (Olweny and Shipho, 2011).

Furthermore, profitability is a reflection of how banks are operating under a given environment. More precisely, it is a mirror image of quality of a bank's management and the shareholder's behavior as well as the banks' risk management capabilities (Aburime, 2007). Profits affect the bank's cost of raising capital directly via contributing to equity financing which is an indicator of the financial strength of the bank. Moreover, even if solvency is high, poor profitability weakens the bank's capacity to absorb negative shocks, which will eventually affect solvency. Consequently, healthy and sustainable profitability is vital in maintaining stability of the banking system and contribute to the state of the financial system (Samuel, 2015).

If a commercial bank does not manage its liquidity well, it will have cash shortages and as a result experience problems paying its obligations when they fall due. Indeed, Refuse (1996) observed that liquidity starvation has generally been credited as a major cause of business failure in many countries. The importance of 
managing liquidity requirements and profitability and must form part of the firms strategic and operational thinking in to operate effectively (Bringham, 2002).

Commercial Bank of Ethiopia (CBE) is the biggest and the oldest bank in Ethiopia with an increasing trend of profitability since 1963. However, liquid asset to total asset ratio of CBE had been decreasing from 2007 to 2015 (CBE, 2016). CBE mobilizes financial resources received from depositors in the form of investment. There is always risk associated with such activity which is mainly emanates from depositors who may withdraw their resources thereby decreasing liquidity position of the banks. Such a problem staggers the bank to meet their obligation which eventually erodes the confidence of the public at large. Ibe (2013) investigated that one of the major reasons that may lead banks to illiquidity and inability to generate profit.

However, there is negligence on liquidity management. Previous studies mainly focused on determinants of liquidity and performance of commercial banks. For example, Tseganesh (2012) identify determinants of commercial banks liquidity in Ethiopia using fixed effect panel regression in eight commercial banks from 2000 to 2011. Besides Workneh (2015) examined the impacts of liquidity on performance of Ethiopian private commercial banks from 2009 to 2014. This study differs from previous ones in that it used an autoregressive disturbed large model (ARDL). We also investigate the causal relationship between liquidity and profitability both in the short-run and long run which was not well addressed by previous studies. We select ARDL model because it does not require all variables to be stationary at first difference and it generally provides unbiased estimates of the long run model and valid t-statistics even when some of the regresses are endogenous. Therefore, the purpose of this study is to examine the short-run and long-run effect of liquidity on profitability in the case of CBE. More specifically, this study investigates the causal relationship between liquidity and profitability both in the short-run and long run situation. It also aims to investigate the causal relationship between loan to deposit ratio and profitability both in short run and long run situation.

\section{Literature Review}

\subsection{Theoretical Literature Review}

The existence, growth and survival of a business organization mostly depend upon the profit. It is true that when profitability increases the value of shareholders may increase to a considerable extent. The term profitability refers to the ability of the business organization to maintain its profit year after year. Profitability of the business organization will definitely contribute to the economic development of a nation by way of providing additional employment for citizens and tax revenue to the government exchequer. Moreover, it contributes to the income of the investors by having a higher dividend and thereby improves the standard of living of the people (Samuel, 2015).

\subsubsection{Liquidity and Profitability in Commercial Banks}

Liquidity term of a commercial bank's balance sheet has two interpretations. First, it refers to the ability of the bank to honor the claims of the depositors. Secondly, it shows the ability of the bank to convert its non-cash assets into cash easily without loss (Saunders and Cornett, 2011). Commercial bank should always have enough cash to meet the demands of the depositors. Thus, the success of a commercial bank depends to a greater extent upon the degree of confidence it can instill in the minds of its funds owners. If the fund owners lose confidence in the ability of their bank to repay depositors, the very existence of the bank will be at stake. So, the bank should always be prepared to meet the claims of the depositors by having enough cash. Among the various items on the assets side of the balance sheet, cash on hand represents the most liquid asset followed by cash with other banks and the central bank (Kidwell et al 2008). The bank cannot have all its assets in the form of cash because cash is an idle asset which does not fetch any return to the commercial bank. So some of the assets of the bank, money at call and short notice, bills discounted, etc. could be made liquid easily and without loss (Saunders and Cornett 2007).

\subsubsection{Liquidity and Solvency Relationship}

While liquidity of a bank relates to its ability to meet short-term commitment when they fall due, solvency is the ability of a bank to ultimately to meet all its obligations (Casu et al., 2006)). For a bank to be solvent means that the value of assets has to be greater than liabilities then the difference between the two being the bank's capital. There are situations in which some assets goes bad, for instance unpaid loans, then the banks must make charges against the loan portfolio that are paid for from retained earnings. When profits are sufficient, then the level of bank capital and its capital adequacy ratio remained unchanged. However, when profits are loss, then losses will have to be written out of capital or alternatively shareholders will be required to provide additional capital to restore the capital ratio to the required level.

The liquidity and solvency position of a bank are related because a severe liquidity shortfall can ultimately result in a solvency problem. If a bank is unable to meet its liquidity requirements it will first attempt to obtained support through the Lender of Last Resort (LOLR) facility by borrowing from the central bank. However, if this option is not available then the bank will have to consider bearing the losses from its capital resources thus reducing the bank's capital position (Johnson, 2002). 


\subsubsection{Banks Liquidity Management Theory}

The major objective of a commercial bank is to create liquidity while remaining financially sound. However, there are a number of dimensions in the way banks manage their liquidity risk. There are competing liquidity management theories. Liquidity management theories encompass how liquidity is measured and monitored, and the measures that banks can take to prevent or tackle a liquidity shortage. These competing theories include: commercial loan theory, shift ability theory.

\subsubsection{Commercial Loan Theory and Liquidity}

Commercial loan theory is a theory of asset management that emphasized liquidity. The theory states that banks should restrict their earning assets to "real" bills of exchange and short-term, self-liquidating advances for commercial purposes. That is individual banking institutions could maintain the liquidity necessary to meet the requirements of deposit withdrawals on demand. Under a somewhat modified character, this basic doctrine came to be known in the U. S. as the commercial loan theory of credit.

The commercial loan theory of credit became obsolete both because of its conceptual flaws and its impracticality. A critical underlying assumption of the theory held that short-term commercial loans were desirable because they would be repaid with income resulting from the commercial transaction financed by the loan. This assumption would certainly not hold during a general financial crisis even if bank loan portfolios did conform to theoretical standards, for in most commercial transactions the purchaser of goods sold by the original borrower had to depend to a significant extent on bank credit. Without continued general credit availability, therefore, even short-term loans backing transactions involving real goods would turn illiquid. Rigid adherence to the orthodox doctrine was, furthermore, a practical impossibility if banks were to play a role in the nation's economic development (Casu, 2006). Moreover, the practice of continually renewing short- term notes for the purpose of supporting long-term capital projects proved unacceptable. The failure or inability of banks to tailor loan arrangements to the specific conditions encountered with longer-term uses in fact contributed to the demise of the practice.

\subsubsection{The Shift ability Theory of Liquidity}

The shift ability theory liquidity replaced the commercial loan theory and was supplemented by the doctrine of anticipated income. The theory held that banks could most effectively protect themselves against massive deposit withdrawals by holding, as a form of liquidity reserve, credit instruments for which there existed a ready secondary market. Included, in this liquidity reserve were commercial paper, prime bankers' acceptances and, most importantly as it turned out, treasury bills. Under normal conditions, all these instruments met the tests of marketability. Major defect in the shift ability theory was discovered similar to the one that led to the abandonment of the commercial loan theory of credit, namely, in times of general crisis the effectiveness of secondary reserve assets as a source of liquidity (Casu et al. 2006)).

The role of the central bank as lender of last resort gained new prominence, and ultimately liquidity was perceived to rest outside the banking system. Furthermore, the soundness of the banking system came to be identified more closely with the state of health of the rest of the economy. This is so because business conditions had a direct influence on the cash flow and thus re-payment capabilities of borrowers. The shift ability theory survived these realizations under a modified form that included the idea of ultimate liquidity in bank loans resting with shift ability to the national bank. Under this institutional scheme, the liquidity concerns of banks were partially returned to the loan portfolio where maintenance of quality assets that could meet the test of intrinsic soundness was paramount (Allen and Gale, 2004).

\subsection{Empirical Literature Review}

There are numerous studies which deal with bank liquidity and profitability although those studies vary to a great extent. There have been a lot of controversial debates among previous studies pertaining to this subject. Some researchers find that there is a significant positive relationship between the two variables while others find a negative correlation. To make this current study more meaningful some references of previous studies from different countries including Ethiopia presented here.

\subsubsection{Empirical Studies in Other countries}

Nimer, Warrad, and Omar (2013) studied whether liquidity through quick ratio has considerable impact on Jordanian banks profitability through return on asset (ROA). They used financial reports of 15 Jordanian banks from 2005-2011. Their study indicated that there is significant impact of quick ratio of return on asset (ROA). This means that profitability through return on assets (ROA) in Jordanian banks is significantly influenced by liquidity through quick ratio.

Akter and Mahmud (2014) investigated the association between liquidity and profitability in the in Bangladesh banking industry. They included twelve banks in four different sectors: Government banks, Islamic banks, multinational banks and private commercial banks). They tried to examine how much liquidity of a bank can explain its profitability. They used a linear regression model from 2006 till 2011 to find out the extent of association among bank's liquidity and profitability. Individually, all the sectors show no significant relationship 
between liquidity and profitability. According to their result, government banks showed changeable liquidity, while other sectors were steady. The authors found that there were many fluctuations in profitability in between these times in all the sectors. Finally, they concluded that based on their sample and category, there is no significant relationship between liquidity and profitability in banks of different sectors in Bangladesh.

Dhanuskodi (2014) examined that the impact of loan deposit ratio on the profitability of Malaysian commercial banks for the period of 2009 to 2013. His study included all the eight locally owned commercial banks in Malaysia. The Loan deposit ratio of the banks was the independent variable of his study. The dependent variable was profitability which measures through return on assets (ROA). The ratio analysis along with descriptive, correlation analysis, paired t- test and regression analysis were used in his study by using annual data obtained from the annual report of the banks. The result of his study found that LDR does not affect ROA.

Mach (2013) sought to establish the relationship between profitability and liquidity of commercial banks in Kenya. Liquid assets are less profitable as compared to long term assets. The dilemma to a finance manager is whether to invest in more profitable long term assets and risk low liquidity or invest in short term assets which are less profitable and therefore reduce return on investment made. The study used secondary data obtained from audited financial statements of the banks to measure profitability and Central Bank of Kenya liquidity ratio and current ratio to measure liquidity in the years 2008 to 2012. The author found that there is a positive relationship between profitability and liquidity of commercial banks in Kenya; however, the coefficients from the study are not significant. Liquidity is found to be one of the determinants of profitability of commercial banks in Kenya over the years of study.

\subsubsection{Empirical Studies in Ethiopia}

There are number of studies conducted in Ethiopia. For example, Tseganesh, (2012) investigated the determinants of commercial bank liquidity in Ethiopia and then seen the impact of banks liquidity up on financial performance through the significant variables explaining liquidity. Balanced fixed effects panel regression was used for the data of eight commercial banks in the sample covered the period from 2000 to 2011. The study finds that capital adequacy, bank size, share of non-performing loans in the total volume of loans, interest rate margin, inflation rate and short term interest rate had positive and statistically significant impact on banks liquidity. Among the statistically significant factors affecting bank are liquidity, capital adequacy and bank size had a positive impact on financial performance, whereas non-performing loans and short term interest rate had a negative impact on financial performance. Therefore, the impact of bank liquidity on financial performance was non-linear/positive and negative.

Workneh (2015) investigated the impact of liquidity on the performance of eight private commercial banks using multilevel linear regression models. To measure performance for three banks, the author used quantitative research approach and secondary financial data which are analyzed by using return on asset (ROA), return on equity (ROE), and net interest margin (NIM). In order to measure liquidity, the author used loan to deposit ratio (LDR), loan to asset ratio (LAR), and liquid asset to deposit ratio (LADR). The study shows that the performance measure, NIM, has a significant relationship with liquidity measures of LDR, LAR and LADR. The other performance measure, the ROE has a positive and significant relationship with LADR; but ROA has a positive and significant relationship with LADR. Finally, the author finds that the impact of liquidity on the financial performance of private commercial banks in Ethiopia was both positive \& negatively related and the significant relationship varies from measure to measure.

This this study investigates the effect of liquidity on profitability focusing on Commercial Bank of Ethiopia (CBE) to examine long-run and short-run relationship between profitability and liquidity. It also examines the directions of causal relationship between the two variables which have been ignored in the literature.

\section{Data collection and Methods of Data Analysis}

In order to analyze the effect of liquidity on profitability of the Commercial Bank of Ethiopian, audited financial statements for 32 consecutive years, i.e., from a period of 1986-2017 was collected. The secondary data that was collected through structured document reviews are mainly from the records held by NBE and the bank itself.

\subsection{Data Analysis and Model Specification}

The study uses time series data. Thus, to determine the nature and extent of the effect of liquidity and profitability, collected data is analyzed by employing correlation technique; regressions \& descriptive statistics. A well-known statistical package, namely Eviwes 10 has been used in order to examine the data. This study employs autoregressive lag distributed (ARDL) co-integration technique.

The choice of ARDL model is based on several considerations; it had more advantages than other time series econometric applications. First, it does not require all variables to be I (1) as the Johansen framework and it is still applicable if we have I (0) and I (1) variables in our set. Second, this technique generally provides unbiased estimates of the long-run model and valid t-statistics even when some of the regressors are endogenous. Harris and Sollis (2003), Inder, (1993) and Pesaran and Shin (1997) have shown that the inclusion of the 
dynamics may help correct the endogenity bias. Third, the bounds test method co-integration has certain econometric advantages in comparison to other methods of co-integration. It is being applied irrespectively the order of integration of the variable. There may be either integrated first order I (1) or I (0). In other word the short-run and long-run coefficients of the model are estimated simultaneously. And then employing this model for our purpose is also necessary parts of the model estimation. Based on Pesaran et al. (2001); the general ARDL estimation starts with an over-parameterized ARDL specification of an appropriate lag order $p, q$; ARDL $(\mathrm{p}, \mathrm{q})$ is:

$$
\begin{gathered}
\mathrm{Y}_{\mathrm{t}}=\beta_{0}+\beta_{1} \mathrm{y}_{\mathrm{t}-1}+\ldots \beta_{\mathrm{k}} \mathrm{y}_{\mathrm{t}-\mathrm{p}}+\alpha_{0} \mathrm{x}_{\mathrm{t}}+\alpha_{1} \mathrm{x}_{\mathrm{t} 1}+\alpha_{2} \mathrm{x}_{\mathrm{t} 2}+\alpha_{2} \mathrm{x}_{\mathrm{t} 2}+\ldots \alpha_{\mathrm{q}} \mathrm{x}_{\mathrm{q}} \\
+\varepsilon_{\mathrm{t}}
\end{gathered}
$$

Formulating unrestricted Error Correction Models (ECM) is important steps of the bound test co-integration. Before we pass to the modern ECM model, let us recall what a conventional ECM for Co-integrated data look like. It would be of the form:

$$
\begin{gathered}
\Delta \mathrm{Y}_{\mathrm{t}}=\beta_{0}+\Sigma \beta_{1} \Delta \mathrm{y}_{\mathrm{t}-1}+\Sigma \mathrm{j} \Delta \mathrm{x}_{1 \mathrm{t}-\mathrm{j}}+\Sigma \delta_{\mathrm{k}} \mathrm{x}_{2 \mathrm{t}} \theta \mathrm{z}_{\mathrm{t}-1} \\
+\varepsilon_{\mathrm{t}}
\end{gathered}
$$

From the equation (3.2), z represents the "error correction term", is the OLS residual series from the long run "co-integrating regression".

\subsection{Model Specification}

In order to determine the dynamic and the simultaneous relationship between liquidity and profitability, given that not all of our time-series may be stationary to the same order (some are I (0) while others are I (1)), the cointegration technique suggested by Pesaran et al., (2001), the autoregressive distributed lag model (ARDL) procedure is used. The approach can be implemented regardless of either all variables are integrated I (1), I (0) or both at the same time and can be applied to small finite samples. Based on empirical literature and diagnostic tests, the long-run relationship between ROA, CR, LDP and OE can be specified as follows:

$$
\begin{aligned}
\ln \text { ROA }_{\mathrm{t}}=\beta_{0} & +\beta_{1} \operatorname{lnCR}_{\mathrm{t}}+\beta_{2} \operatorname{lnLDP}_{\mathrm{t}}+\beta_{3} \operatorname{lnOE}_{\mathrm{t}}+\beta_{4} \text { DUMPOLICY }_{\mathrm{t}} \\
& +\varepsilon_{\mathrm{t}}
\end{aligned}
$$

Where: ROA returns on asset at time t, $\beta 0$ is a constant term, $\beta 1-4$ are coefficients for the respective variables, CR is current ratio, LDP is loan deposit ratio, OE is operating efficiency, and DUMPOLICY is dummy variable for exchange rate policy and $\varepsilon t$ is the disturbance with idiosyncratic error or varies over time. The dependent and independent variables are transformed into natural logarithm. The first step in the ARDL approach to co integration is estimate the following relationship using the OLS estimation technique:

$$
\begin{aligned}
\operatorname{lnROA}_{\mathrm{t}}=\beta_{0} & +\Sigma_{\mathrm{i}=1}^{\mathrm{n}} \beta_{1 \mathrm{i}} \Delta(\operatorname{lnCR})_{\mathrm{t}-\mathrm{i}}+\sum_{\mathrm{i}=1}^{\mathrm{n}} \beta_{2 \mathrm{i}} \Delta(\operatorname{lnLDP})_{\mathrm{t}-\mathrm{i}}+\Sigma_{\mathrm{i}=1}^{\mathrm{n}} \beta_{3 \mathrm{i}} \Delta(\operatorname{lnOE})_{\mathrm{t}-\mathrm{i}} \\
& +\beta_{4}(\mathrm{nCR})_{\mathrm{t}-\mathrm{i}}+\beta_{5}(\ln L D P)_{\mathrm{t}-\mathrm{i}}+\beta_{6}(\operatorname{lnOE})_{\mathrm{t}-\mathrm{i}} \\
& +\varepsilon_{\mathrm{t}}
\end{aligned}
$$

Where $\Delta$ is difference operator; $n$ represents the maximum optimal lag length of the system; the first parts of the equation with $\beta 1, \beta 2, \beta 3$ represents the short-run dynamics of the model and the second parts of the equation with $\beta 4, \beta 5, \beta 6$ represents the long-run phenomenon of the model.

The null hypothesis in this equation is $\mathrm{H} 0: \beta 4=\beta 5=\beta 6=0$, which means the non-existence of a long-run relationship against the alternative $\mathrm{H} 1: \beta 4 \neq \beta 5 \neq \beta 6 \neq 0$ meaning that there is a long-run relationship. The $\mathrm{F}$ test for the coefficients on the one period lagged level of the variables is compared with the $\mathrm{F}$ critical values taken from Pesaran (2001) or Narayan (2005).

Once co-integration is confirmed, we move to the next stage and estimate the long-run coefficients of the level equation (3.9) and the short-run dynamic coefficients via the following ARDL error correction models:

$$
\begin{aligned}
& \Delta(\operatorname{lnROA})_{\mathrm{t}}=\beta_{0}+\Sigma_{\mathrm{i}=1}^{\mathrm{q}} \beta_{1 \mathrm{i}} \Delta(\operatorname{lnCR})_{\mathrm{t}-1}+\Sigma_{\mathrm{i}=1}^{\mathrm{q}} \beta_{2 \mathrm{i}} \Delta(\operatorname{lnLDP})_{\mathrm{t}-1}+\sum_{\mathrm{t}=1}^{\mathrm{q}} \beta_{3 \mathrm{i}} \Delta(\operatorname{lnOE})_{\mathrm{t}-1} \\
& +\lambda \mathrm{ECM}_{\mathrm{t}-1} \\
& +\varepsilon_{1 \mathrm{t}}
\end{aligned}
$$

Where ECMt-1 is one lag error correction term that must be negative; $\lambda$ is the adjustment speed to the equilibrium after a shock. The coefficients of equation $3.9\left(\beta_{1} i, \beta_{2} i, \beta_{3 i}\right)$ are the coefficients for the short run dynamics of the model's convergence to the equilibrium and ctare the error terms. Finally, since the ARDL test checks for the presence of a long-term relationship or, in other words, co-integration, but does not indicate the direction of causality, the standard causality test of Granger (1988) was also applied in this study. So by using 
ARDL model we determine whether cause-and-effect relationship exists between liquidity and profitability. We used ROA for measuring profitability, and current ratio and the loan to deposit ratio were used to measure liquidity of the $\mathrm{CBE}$.

\section{Results and Discussion}

The descriptive statistics are used to describe and summarizes the characteristics of the data. Under this subsection, some descriptive statistics of the measure of central tendencies (mean and median) and measure of dispersion of the series under the study are presented. In addition to these, the normality of each variable is tested by using Jarque-Bera test with the corresponding probability value; the guide line for this test is probability value should be greater than 0.05 standard level of significance. Therefore, as we have seen all the variables probability values are greater than $5 \%$ and we can concluded that all the variables incorporated in the analysis are normally distributed with zero mean and constant variance.

The first step involves estimating in this model is obtaining the optimal lag length. Even though the ARDL model has an automatic lag selection criterion which is AIC, it is better to know the optimal lag length before proceeding with unit root test. Among the following selection criterion this study decided to use Akaike information criterion (AIC). This is because in the ARDL model, the AIC is imputed so that it enables us to make the appropriate comparison with the ARDL model. The result shows that the optimal lag length is selected one.

Testing for the existence of unit roots is of the major interest in the study of time serious models and cointegration. The presence of a unit root implies the time serious under investigation is non-stationery while the absence of a unit root shows that the stochastic process is stationary. This research applied the ADF test and adjusts the DF test to take care of the possible serial correlation in the error terms by adding the lagged difference of the dependent variable. Akaike information criterion (AIC) is used to determine the lag length. We have to give priority for $\mathrm{p}$-value rather that $\mathrm{t}$-statistic ( $\mathrm{t}$-statistic is the necessary condition but not sufficient conditions for to check stationary of the series rather than $\mathrm{p}$-vale is the sufficient condition).

The results from ADF unit root test shows that the two variables (LDR and OE) are stationery in level at $5 \%$ of significance and the remaining variables are stationery in first difference, with intercept and/or intercept and trend. In other word there is no variable that is stationery in second difference and such results of ADF unit root test is one justification for using the ARDL approach (bound test approach of co-integration) developed by Pesaran, Shin, and Smith (2001).

Philips-Perron (pp) unit root test also shows like that of ADF table result that one variable (k) is stationery in level and the remaining variables are stationery in their first difference; with intercept and /or intercept and trend. Thus, both tests revealed that, the model is mixtures of variables that are integrated of order one and zero. That is, I(1) and I(0) none of the variables are found to be integrated of order two. Therefore, ARDL or bound testing approach to co-integration is the preferred and appropriate method of regression in this case.

To check the reliability and verifiability of the estimated long-run and short-run models, diagnostic tests are undertaken. These tests include serial correlation (Brush and Godfray LM test), functional form (Ramsey's RESET test), Normality (Jaque-Bera test), Hetroscedasticity (Breusch-Pagan-Godfrey test) and also CUMSUM recursive residuals and CUMSUM square recursive residuals tests are applied to check the overall stability of the long-run and short-run coefficients which are recommended by Pesaran et al. (2001).

We cannot reject the null hypothesis of there is serial correlation (Breusch-Godfrey Serial Correlation LM Test) because all model of the probability value related with test statistics is greater than the standard significant level of 5\%. Besides, Ramsey's RESET test indicates that we do not have any evidence to reject null hypothesis of the Ramsey's test, which means that the model is correctly specified. The remaining diagnostic test is Hetroscedasticity test. We do not have any evidence to reject the null hypothesis at $5 \%$ significant level because the p-value associated with both the observed R2 version and F-version is greater than $5 \%$.

In order to checking whether the error term of each model is normally distributed or not, by applying Jarque-Bera test. Therefore, we have check that the error term of model are normally distributed, because Jarque-Bera probability-values are greater than 5\% and we have to accept the null hypothesis. The parameters of the model are stable. Because the plots of cumulative sum of square recursive residuals of a models which are indicated by the blue lines are lies between the two critical values indicated the red lines (i.e. the upper and lower bound critical values.

\subsection{Long run ARDL model for co-integration}

From the previous sub-sections, we determine the stationary nature of the model, the maximum lag length of the variables, stability of model, and normality of the error terms of the model. The next task is the bounds test approach is estimating the ARDL model, using the appropriate lag length which is automatically selected by the ARDL model itself. The long run ARDL bound for integration is used to check whether a given macroeconomic variables have long run association ship or not. In analyzing co-integration nature of the time series data the 
Wald test also applicable, but according to Nkoro and Uko (2016) recommended that the Wald test is applicable if there is a single long run relationship and a sample data size is less than or equal to 30 . This study use 32 years data; therefore, we have to apply ARDL co-integration approach rather than Wald test.

Table 1: The long run ARDL bound test

\begin{tabular}{|l|l|l|l|}
\hline \multirow{2}{*}{ Level of significance } & Critical value & \multirow{2}{*}{ F-statistics } \\
\cline { 2 - 3 } & Lower bound & Upper bound & \\
\cline { 1 - 3 } $10 \%$ & 2.2 & 3.09 & \multirow{3}{*}{5.544908} \\
\hline $5 \%$ & 2.56 & 3.49 & \\
\hline $1 \%$ & 2.88 & 3.87 & \\
\hline Number of observation & 3.29 & 4.37 & \\
\hline
\end{tabular}

Note; $* * *, * *$ and $*$ denotes the variables are significant at $1 \%, 5 \%$ and $10 \%$ levels of significance.

Source: Authors computations

As shown in Table 1, the calculated F-statistics is 5.544 and this value is higher than the upper bound critical values at 5\% level of significance. The results indicate that there is strong evidence of long-run relationship or co-integration between log of ROA and the remaining variables such as current ratio (CR), loan to deposit ratio (LDR), operating efficiency $(\mathrm{OE})$ and exchange ret policy interesting. This represents a cointegrated ROA of CBE. Thus, the null hypothesis of no co-integration between ROA per capita and its fundamentals is rejected.

\subsection{The Long Run Estimated Coefficient of the entire Selected ARDL Model.}

After approving the presence of the long run co-integration relationship among the variables, the next procedure is running the long run and short run model, but ARDL model can estimate both the short run and long run model simultaneously, which is reported in Table 2 .

Table 2: Estimated Long Run Coefficients Using ARDL Approach

Model (ARDL $(2,2,2,1,2))$

\begin{tabular}{|l|l|l|l|l|}
\hline & & & & \\
Repressor & Coefficient $(\boldsymbol{\beta}$ 's) & Std. Error & t-Statistic & Prob. $^{*}$ \\
\hline LnCR & 7.185797 & 3.951056 & 1.818703 & $0.0877^{*}$ \\
\hline LnLDR & -15.64691 & 7.686111 & -2.035738 & $0.0587^{*}$ \\
\hline LnOE & -5.451926 & 2.555065 & -2.133772 & $0.0487^{* *}$ \\
\hline DUMPOLICY & -5.554545 & 3.486236 & -1.593279 & 0.1307 \\
\hline C & 54.30642 & 24.12309 & 2.251221 & $0.0388^{* *}$ \\
\hline
\end{tabular}

Note; $* * * * *$ and $*$ denotes the variables are significant at $1 \%, 5 \%$ and $10 \%$ levels of significance.

Source: Authors computations

$L N R O A_{t}=54.31+7.19 L_{N C R_{t}}+-15.65 L N D R_{t}-5.45 L N L D R_{t}-5.55$ Policy $_{t}+\varepsilon_{t}$

The result presented in Table 2 indicates that all the variables except exchange rate policy change entered the model with statistically significant coefficient in the long run at their respective significant level. As expected, loan to deposit ratio affects return on asset in the case of the Commercial Bank of Ethiopia in the long run. $1 \%$ percent increase in loan to deposit ratio leads to a $15.65 \%$ decline in profitability keeping other factors constant. This indicates that the bank is issuing out more of its deposits aiming at getting super profits so they ended up giving loans to their clients without enough analysis of risks. As a result most of the loan gets to non-performing loans (NPL) or bad loans.

In CBE scenario, total deposits come from customers and placements from other banks and other financial institutions. Deposits from customers include demand deposits, savings deposits and fixed time deposits and there is an improvement in deposit and then profitability from year to year. For example, in the year 2016/2017 the total deposit of CBE is around 364.9 billion Birr which increased by 76 billion Birr as compared to the last year and also net profit after tax was 9.7 billion Birr which increased by 6.3 million Birr as compared to preceding year. Moreover, the total loans shown in the balance sheet in the name of loans and advances and includes term loans like domestic trade and service, import/or export advances and guarantees, loans/or financing to financial institutions, resolving credits and staff loans. For witness in the year 2016/17, the gross loan and advances of CBE is around 89 billion Birr which increased by 27 billion Birr as compared to the last year.

Many previous studies, like Bourke (1989), Valverde and Fernandez (2007), Dietrich and Wanzenried, (2011) and Fadare (2011) are also in line with this result. The study by Bourke, (1989) for instance points out that liquidity ratios, particularly loan to assets, loan to deposits and cash ratios which contains data that are inherent in banks' financial statement can affect profitability positively. As opposed to capital based return, their finding reveals that liquidity ratios and interest margin are positively related to bank profitability. Operating 
efficiency is another significant and determinant variable that affect profitability positively in the long-run. From the estimated result, the coefficient value of operating efficiency is (-5.451) and it is statistically significant at $10 \%$. The coefficient of the ratio of cost to income which is a proxy for operating efficiency provides information on the efficiency of the bank regarding expenses relative to income. An increase in operating efficiency $10 \%$ will decrease profitability by $5.45 \%$. Currently, the hiring of quality labor and improvement in the performance of the total number of employees contribute to the increase in the profit of Commercial bank of Ethiopia. This result is consistent with the works of Athanasoglou et al. (2005), Ramlall, (2009) and Birhanu, (2012). The result reinforces the argument that an increase/or decrease in operating efficiency of the bank will increase/or reduce profitability. Finally, from the estimated result shown in Table $6, \operatorname{lnLDP}$ and lnOE negetively affect $\operatorname{lnROA}$ in the long-run and they are statistically significant at ten the percent level of significance. However, there is a positive and significant long-run relationship between $\operatorname{lnCR}$ and $\ln R O A$.

\subsection{Short Run Error Correction Model (ECM) for the Entire Three Models}

Afterward the acceptance of the long run coefficients of the ARDL estimated equation, the short run ECM model is assessed. The coefficient of the error correction term depicts that how quickly variables converge to equilibrium. The guideline is that the error correction term should have negative sign and statically significant at the standard significant level, this means the probability value should be less than $5 \%$.

Table 3: The short run (Error Correction) models representations for the selected ARDL $(2,2,2,1,2)$

Model (ARDL $(2,2,2,1,2))$

\begin{tabular}{|l|l|l|l|l|}
\hline Repressor & Coefficient( $\beta$ 's $)$ & Std. Error & t-Statistic & Prob. $^{*}$ \\
\hline $\mathrm{D}($ LnROA(-1)) & -0.290760 & 0.123573 & -2.352953 & 0.0317 \\
\hline $\mathrm{D}($ LnCR) & 0.168592 & 0.310596 & 0.542800 & 0.5947 \\
\hline $\mathrm{D}($ LnCR(-1)) & -1.427089 & 0.273305 & -5.221606 & 0.0001 \\
\hline $\mathrm{D}($ LnLDR) & -2.303955 & 0.415520 & -5.544748 & 0.0000 \\
\hline $\mathrm{D}($ LnLDR(-1)) & 0.922605 & 0.427951 & 2.155869 & 0.0467 \\
\hline $\mathrm{D}($ LnOE) & -2.228049 & 0.317761 & -7.011706 & 0.0000 \\
\hline $\mathrm{D}(\mathrm{DUMPOLICY)}$ & -0.984182 & 0.423013 & -2.326598 & 0.0334 \\
\hline $\mathrm{D}(\mathrm{DUMPOLICY}(-1))$ & 2.641459 & 0.429706 & 6.147137 & 0.0000 \\
\hline (ECT (-1)) & -0.254435 & 0.038504 & -6.608037 & 0.0000 \\
\hline Adj-R & 0.828071 & & \\
\hline
\end{tabular}

Note: $* * * * *$ and $*$ denotes the variables are significant at $1 \%, 5 \%$ and $10 \%$ levels of significance.

Source: Authors computations

Short-run estimated results are shown in Table 3. The adjusted-R 2 is 0.828 suggesting that such error correction model fits the data reasonably well. The short-run estimation result suggests that the immediate impact of changes in the dummy variable of structural break has a negative and significant impact on profitability at the five percent level of significance.

The value of the Birr against the U.S dollar has steadily depreciated since the implementation of the managed floating exchange system. In January 2000, the rate was determined at U.S $\$ 1$ : Br 8.2. Accordingly, Ethiopia currency has remained relatively stable, especially in compression to other currencies of most other sub-Saharan African nations, as a result of conservative monetary policy and considerable foreign exchange reserves. Unlike that of the long-run analysis, current ratio D(LNCR) does not have an impact on return on asset or profitability (ROA). Besides to this, in the short run, D(LNLDR) and D(LNOE) has negative and significant effect on ROA at 5\% significance level. This negative coefficient of loan to deposit ratio indicates that when $\mathrm{D}(\mathrm{LnLDR})$ changes by 1 percent point, return on asset (profitability of bank) D(LNROA(-1)) decline by $2.30 \%$ which suggests that liquidity problem can negatively affect Bank profitability and invoke a call for maintaining sufficient liquidity in the short run.

The short run coefficient of operating efficiency also has a significant negative profitability of bank. Holding other things constant, 1 percent increases in operating efficiency leads to a 2.23 percent decline in bank profitability. This short-run result is consistent with its long-run effect on bank profitability (ROA). The speed of adjustment of any disequilibrium towards long-run equilibrium or the equilibrium error correction coefficient (ECM), estimated (-0.254435) is highly significant and has the correct sign. It implies a very high speed of adjustment to equilibrium after a shock. Approximately 25.44 percent of the disequilibrium from the previous year's shock converges back to the long run equilibrium in the current year and such highly significant error correction term is another proof for the existence of a stable a long-run equilibrium relationship among the variables. The dummy variable for policy change $(\mathrm{dD})$ is significant in the short run also.

\section{Conclusion and Recommendation}

The major concern of this study was to reconcile the conflicting requirements of bank liquidity and bank 
profitability. The shareholders desire maximum profitability as a return on their capital, while the depositors desire for a maximum liquidity as a guarantee for safety and ability to pay their money on demand. The main objectives of this study were to investigate the effect of liquidity on profitability in the case of the Commercial Bank of Ethiopia. To comply with the objective of this research, the study used an appropriate econometric methodology called autoregressive disturbance lag (ARDL) co-integration method for the estimation of variable coefficient. Our finding showed that there is a negative relationship between liquidity and profitability in the short-run. Also there is a negative and significant relationship between LDP and ROA in the long-run. This implies that $\mathrm{CBE}$ can absorb any possible unforeseen shock caused by an unexpected need to decrease in liabilities or increase in assets side of the statement of financial position. Furthermore, we conclude that both illiquidity and excess liquidity are "financial diseases" that can easily erode the profit base of the bank as they affect bank's attempt to attain high profitability-level. Therefore, the bank should focus on how to optimize the liquidity holding level to maximize their profitability.

More specifically, we suggest that the liquidity management of CBE should be more proactive than reactive. The bank should not solely concentrate on profit maximization but also take measures that will ensure effective liquidity management. The measures help to minimize or avoid cases of excessive and deficient liquidity. Thorough risk assessment should be done before availing loans to customers and the bank should keep on using the deposits optimally to lend money to the public. In addition, CBE should implement different effective resource mobilization strategy to increase its deposit level to counter affect loan to deposit ratio. Finally, we suggest further research as to how to achieve the optimal liquidity level in commercial bank Ethiopia.

\section{References}

Aburime, U. (2008). Determinants of Bank Profitability: Company-Level Evidence from Nigeria.[Online]. October 2008.

Akter, A., \& Mahmud, K. (2014).The relationship between liquidity and profitability in the banking industry in Bangladesh. International Journal of Empirical Finance, 2.

Allen, F., and D. Gale. 2004. Financial Intermediaries and Markets, Econometrica72:1023-61. Allen, F., and SantomeroA. M., 1998. The Theory of Financial Intermediation, Journal of Banking and Finance

Athanasoglou, P., Brissimis, S., \& Delis, M. (2008). Bank specific, industry specific and macroeconomic determinants of bank profitability.

Bourke, P. (1989). Concentration and other determinants of bank profitability in Europe, North America and Australia.Journal of Banking \& Finance, CBE.(2015). Financial ratios.

Casu, B., Girardone, C., and Malyneux, P., (2006) Introduction to Banking, Harlow, England, Pearson Education Limited. Saunders,

Dhanuskodi, R. (2014). Impact of Loan Deposit Ratio (LDR) on Profitability: Panel Evidence from Commercial Banks in Malaysia. Paper presented at the Mumbai InternationalConference Mumbai.

Nimer, M., Warrad, H., \& Omar, R. (2013).The impact of liquidity on Jordanian banks profitability through return on asset. Interdisciplinary Journal of Contemporary Research in Business, 5.

Eljelly, A. (2004) "Liquidity-Profitability Tradeoff: An Empirical Investigation in an Emerging Market. "International Journal of Commerce \& Management. Vol. 14, No2, pp. 48-61.

Harris, R., \&Sollis, R. (2003).Applied Time Series Modeling and Forecasting. West Sussex.

Ibe, S. O. (2013). The Impact of Liquidity Management on the Profitability of Banks in Nigeria. Journal of Finance and Bank Management, 1(1), 37-48.

Inder, B. (1993). Estimating long-run relationships in economics: A comparison of different approaches, Journal of Econometrics.

Macharia, W. T. (2013). The Relationship Between Profitability and Liquidity of Commercial banks in Kenya,.(MSc thesis), University of Nairobi.

Pesaran, M., \& Shin, Y. (1997).An Autoregressive Distributed Lag Modeling Approach to Co integration Analysis in S. Strom, (ed) Econometrics and Economic Theory in the $20^{\text {th }}$ Century.

Pesaran, M., Shin, Y., \& Smith, R. (2001).Bounds Testing Approaches to the Analysis of Level Relationships. Journal of Applied Econometrics,

Samuel, A. (2015). Determinants of Commercial Banks Profitability: In the case of Ethiopian commercial banks. (MSc), Addis Ababa University.

Samuel, O. F. (2011). Banking Sector Liquidity and Financial Crises in Nigeria.International Journal of Economic and Finance, 3.

Tseganesh, T. (2012). Determinants of Bank Liquidity and Their Impact on Financial Performance: Empirical Study of Commercial Banks in Ethiopia. (MSc), Addis Ababa University, Ethiopia.

Wilner, B., 2000. The Exploitation of Relationships in Financial Distress: The case of trade credit.

Workneh, Y. (2015). The Impact of Liquidity on Performance: an Empirical Study of Ethiopian Private Commercial banks, (MSc), Addis Ababa University. 